\title{
Türkiye Süper Ligi’nde Oyuncu Değişikliğinin Sağkalım Analizi
}

\author{
Survival Analysis of Player Substitutions in Turkish Super League
}

\author{
Onur Burak ÇELIK, University of Hartford, U.S.A., celik@hartford.edu \\ Orcid No: 0000-0003-3400-5929
}

\begin{abstract}
Öz: Profesyonel futbolda teknik direktörler, müsabaka sırasında en büyük etkiyi oyuncu değişikliği ile yaparlar. Bu çalışmada, 2017-2018 sezonu verileri kullanılarak Türkiye Süper Ligi’ndeki teknik direktörlerin oyuncu değișikliği zamanlamasını etkileyen faktörler sağkalım analizi uygulanarak incelenmiştir. Sonuç olarak, en önemli faktörün müsabaka skoru olduğu belirlenmiştir. Galip takımın teknik direktörü, ilk oyuncu değişikliği kararını ertelerken mağlup takımın teknik direktörü bu kararını daha erken uygulamaya koymaktadır. Ev sahibi takım teknik direktörleri oyuncu değișikliğini müsabaka oynanırken değil devre arasında yapmayı tercih etmektedirler. Puan sıralamasında daha yukarılarda yer alan rakiplerle oynanan müsabakalarda da ilk oyuncu değişiklikleri daha erken yapılmaktadır.
\end{abstract}

Anahtar Kelimeler: Sağkalım Analizi, Hızlandırılmış Başarısızlık Süresi Modeli, Oyuncu Değişikliği, Türkiye Süper Ligi JEL Siniflandirmasi: C41, L83, Z20

Abstract:In professional football, coaches can have the biggest impact during a game through player substitutions. In this study, using data from 2017 2018 season, factors affecting the timing of player substitutions of the coaches in the Turkish Super League are examined by applying survival analysis. As a result, the most important factor is determined as the score of the game. While the winning team's coach postpones the first substitution decision, the losing team's coach implements that decision earlier. The home team's manager prefer to make the substitution in half-time but not during the gameplay. The first player substitution is made earlier in games played against the opponents ranked higher in the point table.

Keywords: Survival Analysis, Accelerated Failure Time Models, Player Substitutions, Turkish Super League JEL Classification: C41, L83, Z20

\section{Giriș}

Avrupa futbolu, kısaca futbol, ülkemizde de takip edilen tüm spor dalları arasında ilk sırada gelir. Bu oyunda sonucu belirleyen ya da doğrudan etki edebilen en önemli aktörler, sahada görev alan sporcular ve teknik direktörlerdir. Bir teknik direktörün bir takımı yönetirken karşılaştığı problemler bir iktisatçının veya bir şirket yöneticisinin karşılaştığ problemlerle benzerlikler taşır. Teknik direktör de elindeki kısıtlı imkânlar ve kıt kaynaklarla belirlenen hedefe ulaşmaya çalışır. Oyuncuları hem fiziksel hem de zihinsel olarak müsabakalara hazırlamak, gerekli antrenmanları yaptırmak, uygulanacak sistem ve taktikleri belirlemek bir teknik direktörün görevleri arasındadır. Bunlara ek olarak teknik direktör, müsabaka öncesinde ve sırasında belirlediği taktik ve oyun stratejisini gözden geçirir. Müsabaka sırasında gelişen olaylar ve durumlar karşısında oyun tarzını veya sahada yer alan oyuncuları değiştirebilmektedir (Frick vd. 2010).

Müniroğlu vd. (2011)'nin Ankara'daki 100 profesyonel futbolcu üzerinde yaptıkları anket çalışmasında "Bir maçın kazanılmasında taktik çok önemlidir.” önermesine futbolcuların \%42'si katılıyorum, \%58'i tamamen katıllyorum cevabı vermiștir. Aynı çalışmada "Taktiklerdeki büyük değişiklikler skora, müsabakanın zamansal gidişine ve rakibin oyun planına göre değişmelidir.” önermesine futbolcuların \%33'ü katılıyorum, \%68'i tamamen katıllyorum cevabını vermiștir. $\mathrm{Bu}$ cevaplar, müsabaka sırasında uygulanan taktiğin ve taktik değişikliklerinin ne kadar önemli olduğunu göstermektedir ancak müsabaka sırasında teknik direktörün oyuna etkisi oldukça sınırlıdır. Karşılaşma öncesinde ve devre arasındaki teknik ve taktik konuşmalar dışında teknik direktörler oyuna en büyük etkiyi oyuncu değisşikliği ile yapabilirler.

Güzel vd. (2013), yaptıkları durum çalıșmasında, görüșme yapılan antrenörlerden birisi “...Bir antrenör ne yaptığını çok iyi bilmelidir. Örneğin bir maçta yaptı̆̆ı yanlış değişiklik takımı olumsuz yönde etkileyebilir..." cevabını vermiş̧ir. Bu nedenle oyuncu değişikliğinin zamanlaması ve hangi oyuncunun oyundan çıkıp hangi oyuncunun oyuna dâhil olacağı kararı oldukça önemlidir. Doğru zamanlama ve doğru oyuncu değişikliği seçimi, kaybedilmek üzere olunan bir müsabakada takımı galibiyete taşıyabilir ya da tam tersi bir etki yapabilir.

Futbolda sportif başarının yakalanmasında teknik direktörün önemli bir rolü vardır. Özellikle müsabaka sırasındaki teknik direktör kararları skora etki edebilecek kadar önem arz eder. Bu nedenle bu çalışmada, Türkiye Süper Ligi'ndeki teknik direktörlerin müsabaka sırasında taktik değișiklik yapabilmek için kullandıkları en önemli araç olan oyuncu değişiklikleri kararlarını belirleyen etkenlerin ortaya çıkarılması amaçlanmıştır. Bunun için 2017-2018 sezonunda oynanan müsabakalardaki oyuncu değişiklikleri incelenmiş ve elde edilen veri üzerine sağkalım analizi uygulanmıştır.

\section{Literatür}

Bilindiği kadarıyla Türkiye Süper Ligi’nde teknik direktörlerin oyuncu değişikliği zamanlamasını belirleyen faktörleri inceleyen bir çalışma bulunmamaktadır. Bu konuda benzer bir çalışma daha önce Del Corral vd. (2008) tarafindan 2004- 
2005 sezonu için İspanya Birinci Futbol Ligi (La Liga) üzerine yapılmıştır. İspanya La Liga'da en belirleyici etkenin oyuncu değişikliğinin yapılacağı andaki müsabaka skoru olduğu belirlenmiştir. Bunun yanında, savunma gücünü artıran değişiklikler hücum gücünü artırmayı amaçlayan değişikliklere göre müsabakada daha geç yapılmaktadır. Ayrıca, La Liga müsabakalarında ev sahibi takımların teknik direktörleri ilk oyuncu değişikliklerini devre arasında yapmayı tercih etmektedirler. Her ne kadar benzerlikler olsa da her ülkede futbol kültürü, eğitimi, taktik anlayışı ve işleyişi farklıdır.

Ölüm, hastalık, evlilik, boşanma, işten ayrılma vb. bir olayın gerçekleştiği ana kadar geçen zamanı etkileyen faktörleri incelemek amacıyla yöntem olarak sağkalım analizi kullanılır. Audas vd. (2000), sağkalım modellerini kullanarak İngiltere'deki profesyonel futbolda teknik direktörlerin görev sürelerini incelemişlerdir. Benzer şekilde Barros vd. (2009), Almanya Bundesliga'daki teknik direktörler üzerinde sağkalım analizi yapmışlardır. Koning (2003) teknik direktör değişikliğinin takım performansına etkisini incelemiştir. Bunların yanında, Balduck vd. (2010), Belçika futbol liglerinde sezon ortasında teknik direktör değişikliklerinin kısa vadede takım performansına etkisini analiz etmişlerdir. Egesoy (2010), 1997 ile 2007 yılları arasında Türkiye Süper Ligi'nde futbol kulüplerindeki teknik direktör değişikliklerini incelemiştir.

Benzer konularda yukarıda bahsedilenler gibi birçok yayın bulunmasına karşın bir teknik direktörün müsabaka sırasında skoru etkileyebilmek amacıyla oyuna müdahale etmek adına kullanabildiği tek araç olan oyuncu değişikliği konusunda Türkiye Süper Ligi üzerine bir çalışma yapılmamıştır. Bu çalışma ile literatürde bu konudaki eksikliğin giderilmesi amaçlanmıştır.

\section{Veri ve Yöntem}

Bugün geçerli olan futbol kurallarına göre teknik direktörler, bir müsabakada sadece üç oyuncu değişikliği yapabilirler. Oyunun başlama düdüğünden bitiş düdüğüne kadar olan zaman süresinde devre arası dâhil herhangi bir anda oyuncu değişikliği haklarını kullanabilirler. Futbol müsabakalarındaki oyuncu değişiklikleri incelendiğinde değişiklik için farklı sebepler olabilir. Bir oyuncunun sağlık durumunun (yaralanması ya da sakatlanmasından dolayı) oyuna devam etmesine imkân vermemesi veya kaleci gibi kritik pozisyonda oynayan bir oyuncunun oyundan ihraç edilmesi nedeniyle teknik direktör oyuncu değişikliği yapma mecburiyetinde kalır. Bu nedenle bazı durumlarda teknik direktörün oyuncu değişikliğinin zamanlaması konusunda bir kontrolü söz konusu olmayabilir. Müsabakaların ilk yarılarında yapılan oyuncu değişiklikleri genellikle bu sebeplerden dolayı yapılan değişikliklerdir. Bu nedenle müsabakanın ilk yarısında yapılan oyuncu değişiklikleri çalışma dışında bırakılmış sadece devre arasında ve ikinci yarısında yapılan değişiklikler ele alınmıştır. Aynı şekilde taktiksel olarak kaleci değişikliği de futbolda pek rastlanan bir durum değildir. Kaleci değişiklikleri genelde ya sakatlık ya da oyundan ihraç nedeniyle gerçekleşir. Bu sebeple kaleci değişiklikleri de çalışmaya dâhil edilmemiştir. 2017-2018 sezonunda oynanan karşılaşmalardaki oyuncu değişikliği verileri, Türkiye Futbol Federasyonu'nun internet sitesinde (www.tff.org.tr) yayınlanan müsabaka istatistiklerinden alınmıştır. Şekil 1'de sezon boyunca bütün karşılaşmalarda yapılan tüm oyuncu değişikliklerinin sayısının dakikalara göre dağılımı gösterilmektedir. Şekilden de anlaşılacağı üzere oyuncu değişikliklerinin büyük çoğunluğu devre arasında ve ikinci yarıda gerçekleşmektedir ve toplam 1794 oyuncu değişikliğinin sadece 85 tanesi $(\% 4,7)$ müsabakanın ilk 45 dakikasında gerçekleşmiştir.

Teknik direktörler tarafından karşılaşmanın son dakikalarında yapılan değişiklikler ise skora etki etme amacından ziyade skoru korumak amacıyla vakit geçirmeye yönelik değişikliklerdir. Bunun için teknik direktörler genellikle üçüncü, bazen de ikinci oyuncu değişiklik haklarını bu amaçla kullanırlar. Bu durum, Şekil 1'de müsabakanın son iki dakikasındaki oyuncu değişikliği sayısındaki artıştan da gözlenmektedir. Bu sebeple teknik direktörlerin kendi iradeleri ile oyuna teknik ve taktik olarak müdahale etme amacıyla verdikleri oyuncu değişikliği kararı, müsabakanın devre arasında ya da ikinci yarısında yaptıkları ilk oyuncu değişikliğidir. Sonuç olarak, 2017-2018 sezonunda Türkiye Süper Ligi'nde oynanan karşılaşmalarda her takımın sadece müsabakanın devre arasında ve ikinci yarısında yaptığı ilk oyuncu değişiklikleri bu araştırmaya dâhil edilmiştir. Bu çalışmanın analizinde de bir müsabakada her iki takımın ilk oyuncu değişikliğini yaptığı ana kadar geçen süre bağımlı değişken olarak kullanılmıştır. 


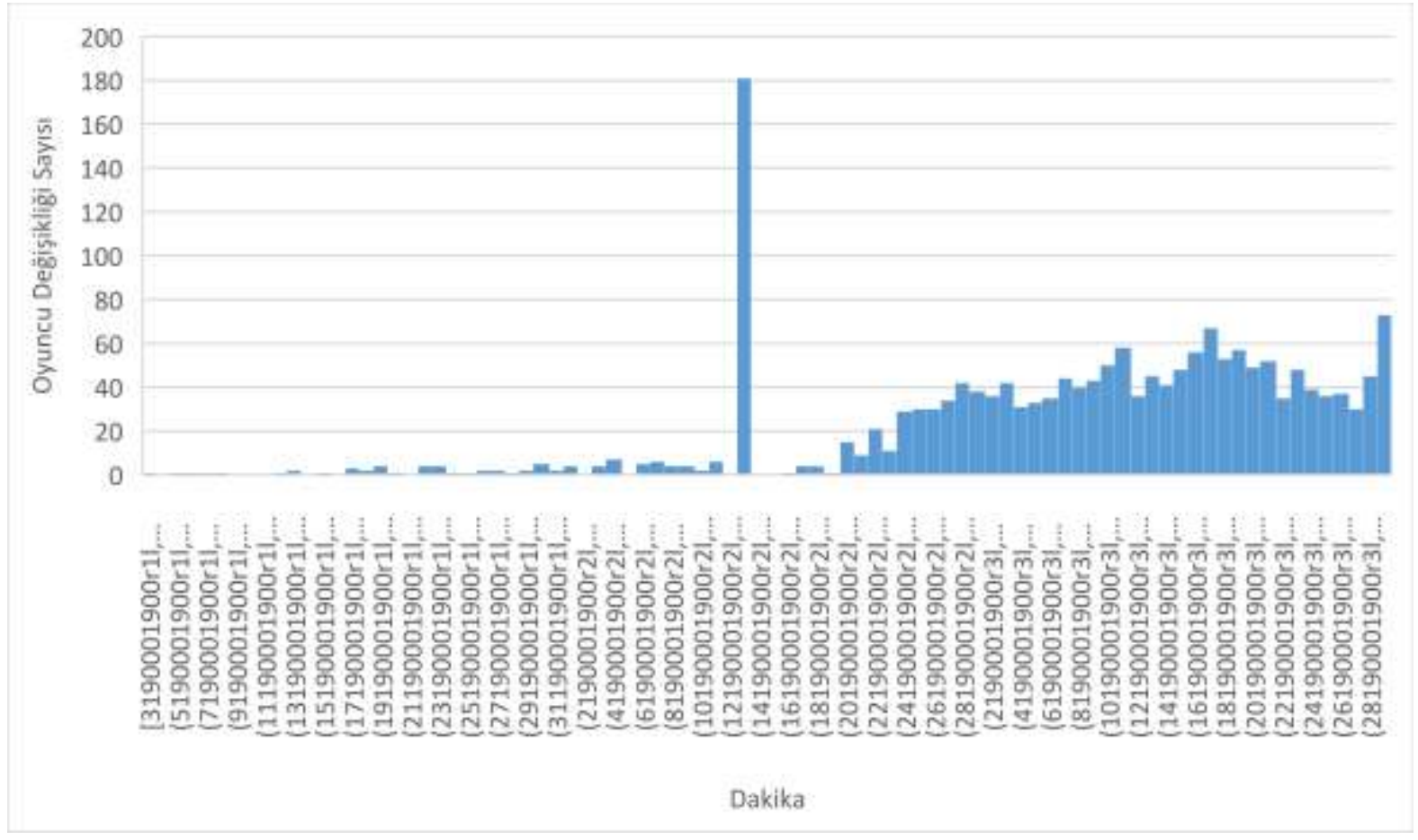

Şekil 1. 2017-2018 Sezonunda Oynanan Bütün Karşılaşmalardaki Tüm Oyuncu Değişikliklerinin Sayısının Dakikalara Göre Dağılımı (Toplam 1794 Oyuncu Değişikliği)

Bu çalışmanın odağında yer alan müsabakanın devre arasında ve ikinci yarısında yapılan ilk oyuncu değişikliklerinin dakikalara göre dağılımı, Şekil 2'de gösterilmektedir. İlk dikkat çeken nokta, ilk oyuncu değişikliğinin açı ara en fazla müsabakanın devre arasında yapıldığıdır. Karşılaşmanın ikinci yarısının başlamasıyla oyuncu değişikliği sayısında tekrar sıfırdan başlayarak müsabakanın 65. dakikasına kadar artış olmakta 65. dakikadan itibaren 90. dakikaya kadar bu sayıda sıfira düşüş gözlenmektedir.

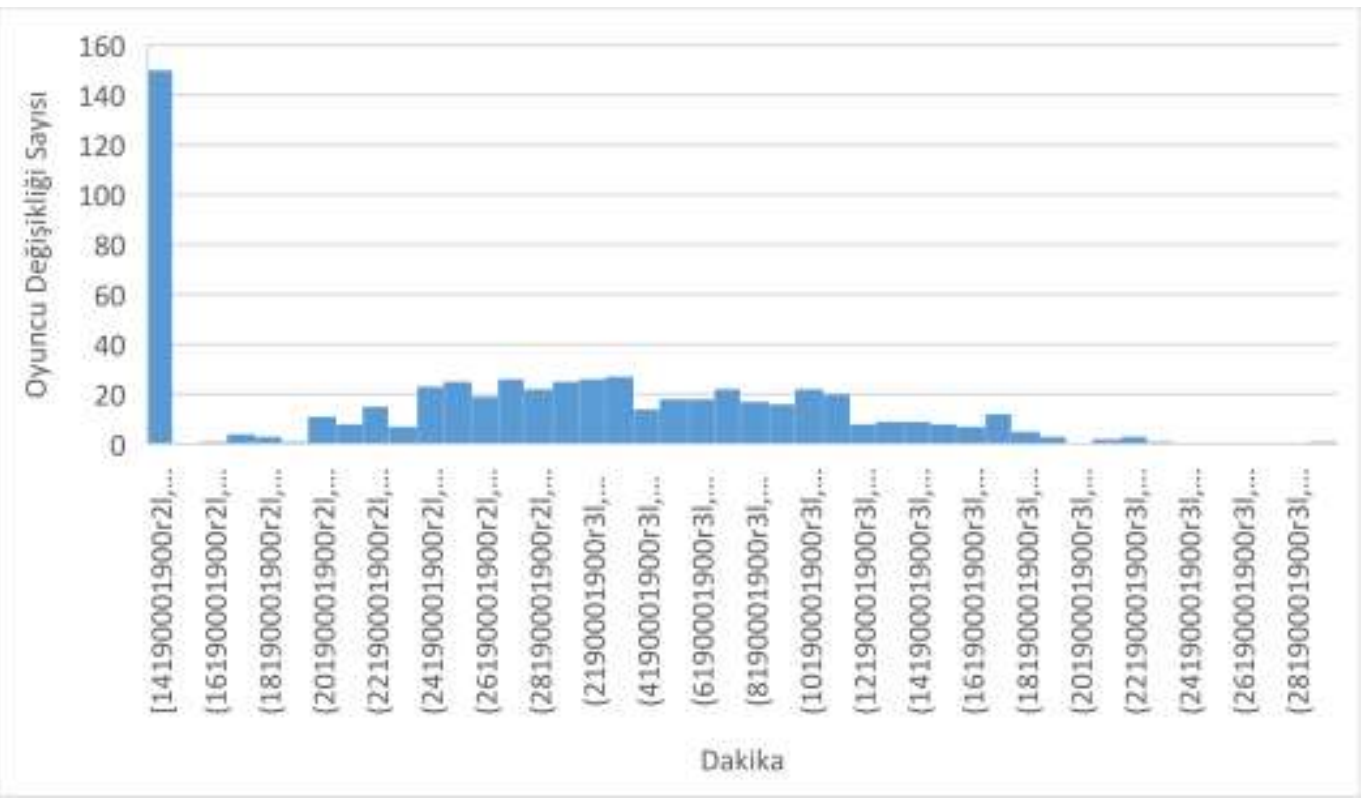

Şekil 2. 2017-2018 Sezonunda Oynanan Bütün Karşılaşmalarda Takımların Müsabakanın Devre Arasında ve İkinci Yarısında Yaptı̆̆ İlk Oyuncu Değişikliklerinin Sayısının Dakikalara Göre Dağılımı (Toplam 608 Oyuncu Değişikliği)

Şekil 3'te ise müsabakaların sadece ikinci yarısında yapılan ilk oyuncu değişikliklerinin sayısının dakikalara göre dağılımı gösterilmiştir. Yine Şekil 2'ye benzer bir dağılım gözlenmektedir. Yapılan oyuncu değişikliklerinin sayısı, sıfırdan başlayarak müsabakanın 65. dakikasına kadar artmakta 65. dakikadan itibaren 90. dakikaya kadar azalmaktadır. 


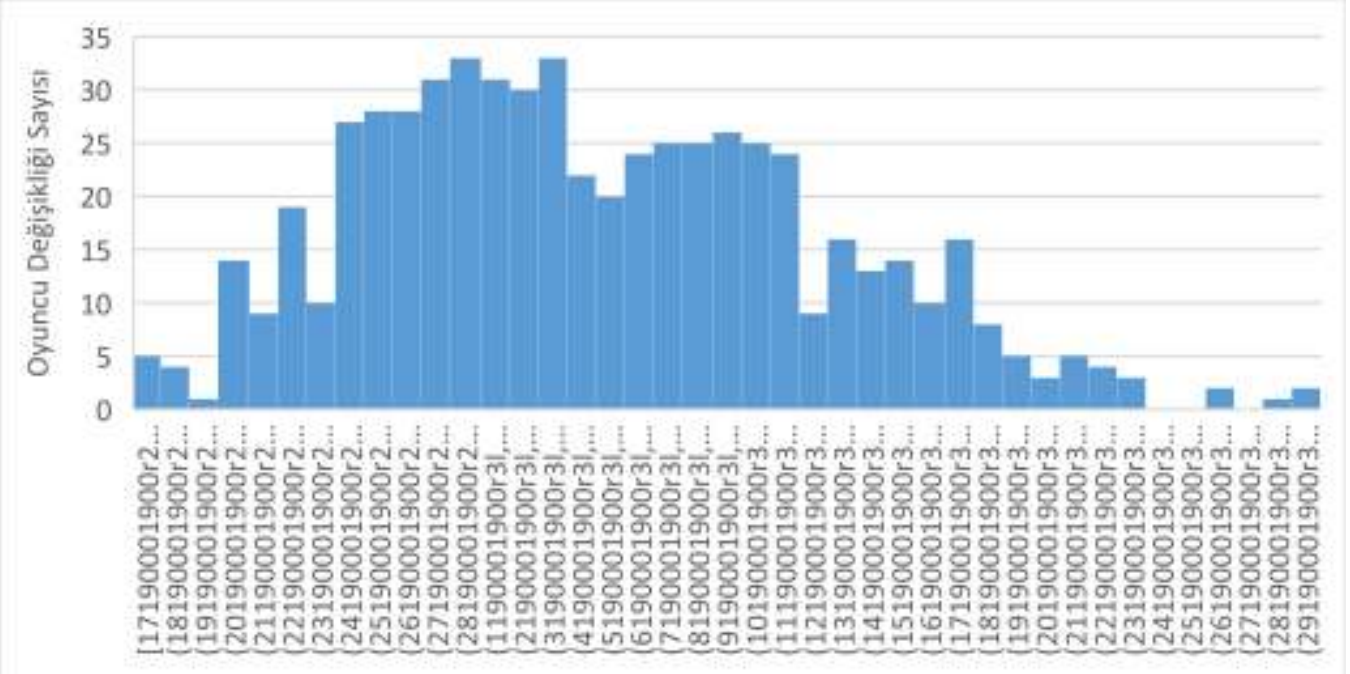

Dakika

Şekil 3. 2017-2018 Sezonunda Oynanan Bütün Karşılaşmalarda Takımların Müsabakanın İkinci Yarısında Yaptığı İlk Oyuncu Değişikliklerinin Sayısının Dakikalara Göre Dağılımı (Toplam 605 Oyuncu Değişikliği)

Sağkalım analiz modellerinde bağımlı değişken belirli bir olayın gerçekleştiği ana kadar geçen zamandır. Sağkalım analizlerinden olan oransal hazard modellerinde bağımsız değişkenlerden birinde gerçekleşen bir birimlik artı̧ıı ya da azalışın olayın gerçekleşme oranını katlayarak etkilediği varsayılır ve bu etki zaman içerisinde her zaman sabittir, etkide bir değişme olmaz. Bir başka sağkalım analiz modeli olan hızlandırılmış başarısızlık modelleri ise zaman geçtikçe olayın gerçekleşme olasılığının hızlanarak arttığı ya da azaldığı durumlarda kullanılır.

Bu çalışma kapsamında, örnek olarak düşünürsek; karşılaşmanın 15. dakikasında 1-0 mağlup duruma düşmek ile karşılaşmanın 60. dakikasında mağlup duruma düşmek teknik direktörlerin ilk oyuncu değişikliği kararında aynı etkiyi yapmayacaktır. Dolayısıyla, müsabaka skorunun etkisi zaman içinde aynı değildir. Bu nedenle sağkalım analiz yöntemleri arasından oransal hazard regresyon modelleri, bu çalışma için uygun değildir. Oyuncu değişikliği sayılarının dağılımındaki artış ve azalışlar hızlandırılmış başarısızlık süresi modellerinin daha uygun olduğunun işaretidir (Del Corral vd. 2008). Üstel dağılım modeli ve Weibull dağılım modeli, hızlandırılmış başarısızlık süresi modelleri arasında yer almalarına rağmen üstel dağılım modeli başarısızlık riskinin zaman içinde sabit olduğu; Weibull dağılım modeli ise başarısızlık riskinin zaman içinde monoton artan ya da monoton azalan olduğu durumlarda uygulanmaktadır. $\mathrm{Bu}$ çalışmada ise oyuncu değişikliği kararlarının sayısında zaman içinde artış ve azalışlar gözlenmektedir. Bu nedenle hızlandırılmış başarısızlık süresi modelleri arasından log-normal regresyon modeli, log-lojistik regresyon modeli ve gamma regresyon modeli en uygun yöntemlerdir. Aralarında küçük farklar olsa da bu modellerde başarısızlık riski, yani bu çalışmada oyuncu değişikliği yapma olasılığı, önce artar daha sonra azalır ya da tam tersi bir durum söz konusu olur. Bu nedenle bu çalışmada hızlandırılmış başarısızlık modellerinden gamma regresyon modeli uygulanmıştır ve analiz için Stata/SE 11.2 yazılım paketi kullanılmıştır.

Sağkalım analizlerinde bağımlı değişken, olayın gerçekleştiği ana kadar geçen süredir. Bu çalışmada bağımlı değişken müsabakanın başlama düdüğünden itibaren devre arası ya da ikinci yarıda yapılan ilk oyuncu değişikliğine kadar geçen toplam süredir. Bu süre, dakika olarak ölçülmüsşür. Tablo 1'de kullanılan bağımsız değişkenlerin listesi ve kısa açıklaması gösterilmektedir. Ev sahibi değişkeni, oyuncu değişikliğini yapan takımın ev sahibi olması durumunda 1 değeri alan kukla değişkendir. Gol farkı ise oyuncu değişikliğinin yapıldığı dakikada değişikliği yapan takım ile rakip takımın attığı goller arasındaki farkı ifade eder. Değişikliği yapan takım, galip ise pozitif; mağlup ise negatif; berabere ise sıfir değeri alır.

Teknik direktör, oyuncu değişikliği ile takımın hücum gücünü ya da savunma gücünü artırmayı planlayabilir. Bazen de mevcut oyun mantalitesini korumak isteyebilir. Hücum gücünü artırmak isteyen bir teknik direktör, bir savunma oyuncusunu çıkarıp bir orta saha oyuncusunu ya da hücum oyuncusunu oyuna dâhil eder veya bir orta saha oyuncusunu çıkarıp bir hücum oyuncusunu oyuna dâhil eder. Bu amaçla yapılan oyuncu değişiklikleri için ofansif değişiklik kukla değişkeni kullanılmıştır. Kukla değişkenler, cinsiyet, eğitim seviyesi, medeni durum, din, meslek vb. sayısal değer almayan kategorik değişkenlerin 0 ya da 1 ile ifade edildiği değişkenlerdir. Benzer şekilde savunma gücünü artırmak isteyen bir teknik direktör ise bir hücum oyuncusunu çıkarıp bir orta saha oyuncusunu ya da savunma oyuncusunu oyuna dâhil eder veya bir orta saha oyuncusunu çıkarıp bir savunma oyuncusunu oyuna dâhil eder. Bu amaçla yapılan oyuncu değişiklikleri için defansif değişiklik kukla değişkeni kullanılmıştır. Mevcut oyun mantalitesini korumak isteyen bir teknik direktör ise çıkan oyuncunun oynadığı pozisyonda oynayan bir oyuncuyu oyuna dâhil eder. Bu durumdaki değişiklikler için ise nötr değişiklik kukla değişkeni kullanılmıştır. Klasman değişkeni oyuncu değişikliğini yapan takımın karşılaşma öncesi ligdeki sıralamasını, rakip klasman değişkeni ise rakip takımın karşılaşma öncesi ligdeki sıralamasını 
ifade etmektedir. $\ddot{U} c ̧$ büyükler ise oyuncu değişikliğini yapan takım Beşiktaş, Fenerbahçe veya Galatasaray olduğunda 1 değeri alan kukla değişkendir. Benzer şekilde, oyuncu değişikliğini yapan takımın rakibi Beşiktaş, Fenerbahçe veya Galatasaray olduğu durumda 1 değeri alan kukla değişken olarak rakip üç büyükler kullanılmıştır. Sezonun ilk haftalarında ya da sonlarına doğru teknik direktörlerin oyuncu değişikliği kararlarının zamanlamasında bir değişiklik olup olmadığını incelemek amacıyla müsabakanın oynandığı karşılaşma takviminin haftasını belirten hafta değişkeni kullanılmıştır. Oyundan çıkan oyuncunun müsabakada sarı kart ile ihtar almış olmasının oyuncu değişikliği kararı üzerindeki etkisini incelemek için sarı kart kukla değişkeni kullanılmıştır. Oyuncu değişikliği kararının zamanlamasında yabancı uyruklu teknik direktörler ile Türk teknik direktörler arasında anlamlı bir farklılığın olup olmadığını incelemek amacıyla yabancı uyruklu teknik direktörler için yabancı teknik direktör kukla değişkeni kullanılmıştır.

Tablo 1. Regresyon Analizinde Kullanılan Bağımsız Değişkenler

\begin{tabular}{|c|c|}
\hline Değişken & Açıklama \\
\hline Ev sahibi & Oyuncu değişikliğini yapan takım ev sahibi takım ise 1 değeri alır. \\
\hline Gol farkı & $\begin{array}{l}\text { Oyuncu değişikliğinin yapıldığı dakikada değişikliği yapan takım ile rakip } \\
\text { takımın attığı goller arasındaki fark. }\end{array}$ \\
\hline Ofansif değişiklik & Hücum gücünü artırmaya yönelik değişiklik. \\
\hline Defansif değişiklik & Savunma gücünü artırmaya yönelik değişiklik. \\
\hline Nötr değişiklik & Mevcut oyun mantalitesini korumaya yönelik değişiklik (referans değer). \\
\hline Klasman & Oyuncu değişikliğini yapan takımın karşılaşma öncesi ligdeki sıralaması. \\
\hline Rakip Klasman & $\begin{array}{l}\text { Oyuncu değişikliğini yapan takımın rakibinin karşılaşma öncesi ligdeki } \\
\text { sıralaması. }\end{array}$ \\
\hline$\ddot{U} c ̧$ büyükler & $\begin{array}{l}\text { Oyuncu değişikliğini yapan takım Beşiktaş, Fenerbahçe veya Galatasaray } \\
\text { olduğunda } 1 \text { değeri alır. }\end{array}$ \\
\hline Rakip üç büyükler & $\begin{array}{l}\text { Oyuncu değişikliğini yapan takımın rakibi Beşiktaş, Fenerbahçe veya } \\
\text { Galatasaray olduğu durumda } 1 \text { değeri alır. }\end{array}$ \\
\hline Hafta & Müsabakanın oynandığı karşılaşma takviminin haftası. \\
\hline Sarl Kart & Oyundan çıkan oyuncu müsabakada sarı kart görmüş ise 1 değeri alır. \\
\hline Yabancı Teknik Direktör & $\begin{array}{l}\text { Oyuncu değişikliğini yapan takımın teknik direktör yabancı uyruklu } \\
\text { olduğunda } 1 \text { değeri alır. }\end{array}$ \\
\hline
\end{tabular}

\section{Bulgular}

İlk olarak kullanılan bağımsız değişkenler arasında çoklu doğrusallık olup olmadığını test etmek amacıyla korelasyon matrisi hesaplanmıştır. Elde edilen sonuca göre hem devre arası ve ikinci yarıda yapılan ilk oyuncu değişiklikleri dikkate alındığında hem de sadece ikinci yarıda yapılan ilk oyuncu değişiklikleri dikkate alındığında 'klasman' ile 'üç büyükler' bağımsız değişkenleri ve 'rakip klasman' ile 'rakip üç büyükler' değişkenleri arasında orta derecede korelasyon belirlenmiştir. Devre arasında ve ikinci yarıda yapılan ilk oyuncu değişiklikleri veri setinde 'klasman' ile 'üç büyükler' değişkenleri arasındaki korelasyon katsayısı 0.5356, 'rakip klasman' ile 'rakip üç büyükler' değişkenleri arasındaki korelasyon katsayısı 0.5154 olarak hesaplanmıştır. Aynı değişkenler arasındaki korelasyon katsayıları sadece ikinci yarıdaki ilk oyuncu değişikliklerinin kullanıldığı veri setinde 0.5317 ve 0.5233 olarak hesaplanmıştır. Bu nedenle her iki veri seti için de üç ayrı model test edilmiştir. Olası bir çoklu doğrusallık problemini önlemek için ilk modelde 'üç büyükler' ve 'rakip üç büyükler' bağımsız değişkenleri regresyona dahil edilmezken, ikinci modelde 'klasman' ve 'rakip klasman' bağımsız değişkenleri regresyon dışında bırakılmıştır. Korelasyon katsayılarının orta derecede olması nedeniyle bütün değişkenlerin dahil edildiği üçüncü bir modele de çalışmada yer verilmiştir. Tablo 2, müsabakanın devre arasında ve ikinci arasında yapılan ilk oyuncu değişikliklerinin üzerine yapılan Gamma regresyon sonuçlarını gösterirken; Tablo 3, sadece ikinci yarıda yapılan ilk oyuncu değişikliklerinin incelendiği Gamma regresyon sonuçlarını listelemektedir. Tablolardaki pozitif değerler, oyuncu değişikliği kararının ertelendiği -yani müsabakanın ilerleyen dakikalarında oyuncu değişikliğine gidildiği- anlamına gelirken; negatif değerler, oyuncu değişikliklerinin daha erken yapıldığını göstermektedir. 
Tablo 2. Devre Arasında ve İkinci Yarıda Yapılan İlk Oyuncu Değişiklikleri Üzerine Uygulanan Gamma Regresyon Modeli Sonuçları $(\mathrm{n}=608)$

\begin{tabular}{lccc}
\hline & Model Ia & Model IIa & Model IIIa \\
\hline Sabit & $4.165^{* * *}$ & $4.102^{* * *}$ & $4.164^{* * *}$ \\
Ev sahibi & $(0.024)$ & $(0.019)$ & $(0.029)$ \\
& $-0.029^{* *}$ & $-0.024^{*}$ & $-0.028^{* *}$ \\
Gol farkı & $(0.013)$ & $(0.013)$ & $(0.133)$ \\
& $0.047^{* * *}$ & $0.044^{* * *}$ & $0.047^{* * *}$ \\
Ofansif değişiklik & $(0.005)$ & $(0.005)$ & $(0.005)$ \\
& -0.006 & -0.009 & -0.006 \\
Defansif değişiklik & $(0.016)$ & $(0.016)$ & $(0.016)$ \\
& 0.021 & 0.022 & 0.021 \\
Klasman & $(0.018)$ & $(0.018)$ & $(0.018)$ \\
Rakip Klasman & -0.0004 & - & -0.0002 \\
Üç büyükler & $(0.0012)$ & & $(0.002)$ \\
Rakip üç büyükler & $-0.006 * * *$ & - & $-0.006 * * *$ \\
Hafta & $(0.001)$ & 0.013 & $0.007)$ \\
Sarı Kart & - & $(0.018)$ & $(0.021)$ \\
Yabanci Teknik Direktör & & $0.034 *$ & -0.007 \\
Akaike Bilgi Ölçütü & - & $(0.018)$ & $(0.021)$ \\
& & 0.0004 & 0.0004 \\
& 0.0004 & $(0.0007)$ & $(0.0007)$ \\
& $(0.0007)$ & 0.008 & 0.012 \\
& 0.012 & $(0.018)$ & $(0.018)$ \\
& $(0.018)$ & 0.01 & 0.014 \\
& 0.013 & $(0.017)$ & $(0.017)$ \\
\end{tabular}

Devre arasında ve ikinci yarıda yapılan ilk oyuncu değişikliklerinin incelendiği analiz sonuçlarının verildiği Tablo 2'deki Akaike bilgi ölçütleri karşılaştırıldığında 'klasman' ve 'rakip klasman' değişkenlerinin kullanıldığı modelin 'üç büyükler' ve 'rakip üç büyükler' değişkenlerinin kullanıldığı modele göre daha iyi performans gösterdiği görülmektedir. Sadece ikinci yarıdaki ilk oyuncu değişikliklerinin analiz sonuçlarının yer aldığı Tablo 3'teki Akaike bilgi ölçütü karşılaştırmalarına göre ise aralarında çok az bir fark olmasına karşın bütün değişkenlerin dâhil edildiği model en iyi tahmini yapmaktadır.

Tablo 3. İkinci Yarıda Yapılan İlk Oyuncu Değişiklikleri Üzerine Uygulanan Gamma Regresyon Modeli Sonuçları $(n=605)$

\begin{tabular}{|c|c|c|c|}
\hline & Model Ib & Model IIb & Model IIIb \\
\hline \multirow[t]{2}{*}{ Sabit } & $4.14 * * *$ & $4.138 * * *$ & $4.143^{* * *}$ \\
\hline & $(0.018)$ & $(0.014)$ & $(0.021)$ \\
\hline \multirow[t]{2}{*}{ Ev sahibi } & -0.001 & 0.001 & -0.001 \\
\hline & $(0.01)$ & $(0.01)$ & $(0.01)$ \\
\hline \multirow[t]{2}{*}{ Gol farkl } & $0.011 * * *$ & $0.008 * *$ & $0.01 * * *$ \\
\hline & $(0.004)$ & $(0.003)$ & $(0.004)$ \\
\hline \multirow[t]{2}{*}{ Ofansif değişiklik } & 0.01 & 0.008 & 0.009 \\
\hline & $(0.012)$ & $(0.011)$ & $(0.012)$ \\
\hline \multirow[t]{2}{*}{ Defansif değişiklik } & 0.009 & 0.012 & 0.01 \\
\hline & $(0.013)$ & $(0.013)$ & $(0.013)$ \\
\hline \multirow[t]{2}{*}{ Klasman } & 0.0006 & 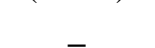 & 0.001 \\
\hline & $(0.0009)$ & - & $(0.001)$ \\
\hline \multirow[t]{2}{*}{ Rakip Klasman } & -0.0009 & - & $-0.002 *$ \\
\hline & $(0.0009)$ & & $(0.001)$ \\
\hline \multirow[t]{2}{*}{ Üç büyükler } & (2) & 0.013 & 0.022 \\
\hline & - & $(0.013)$ & $(0.015)$ \\
\hline \multirow[t]{2}{*}{ Rakip üç büyükler } & _ & -0.015 & $-0.028 *$ \\
\hline & 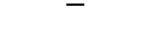 & $(0.013)$ & $(0.015)$ \\
\hline Hafta & $0.001 * *$ & $0.001 * *$ & $0.001 * *$ \\
\hline
\end{tabular}




\begin{tabular}{lccc} 
& $(0.0005)$ & $(0.0005)$ & $(0.0005)$ \\
Sarı Kart & 0.001 & 0.003 & 0.003 \\
Yabancı Teknik Direktör & $(0.012)$ & $(0.012)$ & $(0.012)$ \\
Akaike Bilgi Ölçütü & -0.001 & -0.002 & 0.0008 \\
& $(0.012)$ & $(0.012)$ & $(0.012)$ \\
\hline
\end{tabular}

\section{Tartışma}

Müsabakaların devre arasında ve ikinci yarısında yapılan ilk oyuncu değişiklikleri üzerine uygulanan Gamma regresyon sonuçlarına göre ev sahibi takım teknik direktörü misafir takımın teknik direktörüne göre daha erken oyuncu değişikliği yapmaktadır. Sadece ikinci yarıda yapılan ilk değişikliklerin incelendiği modelde ise ev sahibi takım teknik direktörünün oyuncu değişikliği zamanlaması konusunda anlamlı bir fark bulunamamıştır. Dolayısıyla ev sahibi takım teknik direktörleri, seyirci tepkisi ve baskısından dolayı oyuncu değişikliklerini müsabakaların ikinci yarısı yerine devre arasında, soyunma odasında yapmayı tercih etmektedirler. Uygulanan bütün modellerde en anlamlı ve etkili değişken, oyuncu değişikliğinin yapılacağı sıradaki müsabaka skorudur. Müsabaka sırasında galip olan takımın teknik direktörü, ilk oyuncu değişikliği kararını ertelerken mağlup takımın teknik direktörü ilk oyuncu değişikliğini daha erken yapmaktadır. Skordaki fark arttıkça mağlup takımın teknik direktörü, ilk oyuncu değişikliğini daha da öne çekerken galip takımın teknik direktörü oyuncu değişikliği kararını daha da ötelemektedir. Elde edilen bu sonuçların Del Corral vd. (2006)'nin bulgularıyla uyumlu olduğu gözlenmektedir.

Literatürde daha önceki çalışmalardan farklı olarak Türkiye Süper Ligi'nde savunma gücünü ya da hücum gücünü artırmaya yönelik değişikliklerin teknik direktörlerin ilk oyuncu değişikliği zamanlaması üzerinde herhangi bir etkisi olmadığ1 görülmüştür. Aynı şekilde, takımın o hafta puan sıralamasındaki yerinin de müsabaka sırasında ilk oyuncu değişikliği kararının zamanlaması üzerinde bir etkisi bulunmamıştır. Ancak devre arasında ve ikinci yarıdaki ilk oyuncu değişikliklerinin incelendiği modelde, rakip takımın puan sıralamasındaki yerinin teknik direktörün oyuncu değişikliğinin zamanlaması üzerinde anlamlı bir etkisi olduğu bulunmuştur. Sıralamada daha yukarılarda yer alan rakiplerle oynanan karşılaşmalarda ilk oyuncu değişiklikleri daha erken yapılmaktadır. Sadece ikinci yarıda yapılan ilk oyuncu değişikliklerinin dikkate alındığ 1 analizde ise bütün bağımsız değişkenlerin dâhil edildiği modelde aynı sonuca ulaşılırken 'klasman' ve 'rakip klasman' değişkenlerinin kullanıldığı modelde anlamlı bir fark bulunamamıştır.

Üç büyük kulüp (Fenerbahçe, Galatasaray, Beşiktaş) teknik direktörleri ile diğer kulüp teknik direktörleri arasında ilk oyuncu değişikliğinin zamanlamasında anlamlı bir fark yoktur. Ancak devre arasında ve ikinci yarıda yapılan ilk değişiklikler incelendiğinde bu üç büyük kulüpten birine karşı oynanan müsabakalarda teknik direktörler, ilk oyuncu değişikliği kararlarını ertelemektedirler. Bütün değişkenlerin dâhil edildiği modelde ise anlamlı bir fark bulunamamıştır. Buna karşın, sadece ikinci yarıda yapılan değişiklikler dikkate alındığında üç büyüklerle oynanan karşılaşmalarda ilk oyuncu değişiklikleri daha erken yapılmaktadır.

Teknik direktörün Türk ya da yabancı olması ve oyundan çıkan oyuncunun müsabakada daha önce sarı kart görmüş olmasının ilk oyuncu değişikliği kararında anlamlı bir etkisi olduğu tespit edilememiştir. Devre arasında ve ikinci yarıda yapılan ilk değişikliklerde müsabakanın hangi haftada oynandığının anlamlı bir etki yaratmadığı bulgusuna ulaşılırken sadece ikinci yarıdaki ilk değişiklikler ele alındığında bütün modellerde sezonun ilerleyen haftalarında ilk oyuncu değişikliklerinin de daha geç yapıldığı görülmektedir.

\section{Sonuç}

Bu çalışmada yapılan analizde test edilen bütün modeller göz önünde bulundurulduğunda Türkiye Süper Ligi’nde görev alan teknik direktörlerin ilk oyuncu değişikliği zamanlamasını etkileyen en önemli faktörün müsabaka skoru olduğu tespit edilmiştir. Teknik direktör, müsabaka sırasında takımı galip iken oyuncu değişikliğini daha geç yaparken, mağlup durumda iken oyuncu değişikliği hakkını daha erken kullanmaktadır. Teknik direktörlerin oyuncu değişikliklerini müsabaka sırasında değil devre arasında yapmayı tercih etmeleri de bu çalışmanın bir diğer önemli sonucu olmuştur. Takımın hücum ya da savunma gücünü artırmayı amaçlayan oyuncu değişiklikleri de zamanlama konusunda anlamlı bir fark yaratmamaktadır. Bunların yanında oyundan çıkan oyuncunun müsabakada sarı kart görmüş olmasının ve teknik direktörün yerli ya da yabancı olmasının oyuncu değişikliğinin zamanlamasında bir etkisi olmamaktadır.

Sonuç olarak, teknik direktörler müsabaka skoruna bağlı olarak oyun sırasında uygulanan takım taktiğinde ve oyun planında değişiklik yapmak için oyuncu değiştirmeye karar verirler. Bunun dışındaki faktörler ikinci derecede öneme sahiptir ya da oyuncu değişikliği kararına etki etmemektedir. 


\section{KAYNAKÇA}

Audas, Rick, Stephen Dobson, ve John Goddard. "Organizational Performance and Managerial Turnover." Managerial and Decision Economics 20, no. 6 (1999): 305-18.

Balduck, Anne-Line, Marc Buelens, ve Renaat Philippaerts. "Short-Term Effects of Midseason Coach Turnover on Team Performance in Soccer.” Research Quarterly for Exercise and Sport 81, no. 3 (2010): 379-83.

Barros, Carlos Pestana, Bernd Frick, ve José Passos. "Coaching for Survival: the Hazards of Head Coach Careers in the German 'Bundesliga."” Applied Economics 41, no. 25 (2009): 3303-11.

Corral, Julio Del, Carlos Pestana Barros, ve Juan Prieto-Rodríguez. "The Determinants of Soccer Player Substitutions." Journal of Sports Economics 9, no. 2 (September 2007): 160-72.

Egesoy, Halit. "Türkiye Futbol Süper Ligi teknik direktör değişikliklerinin incelenmesi." Pamukkale Journal of Sport Sciences 1, no 2 (2010): 37-48.

Frick, Bernd, Carlos Pestana Barros ve Joachim Prinz. "Analysing head coach dismissals in the German "Bundesliga" with a mixed logit approach." European Journal of Operational Research 200, no. 1 (2010): 151-9.

Güzel, Pınar, Zeynep Gökçe Onağ, ve Selhan Özbey. "Futbol antrenörlerinin görüşlerine göre takım başarısını etkileyen faktörler: Nitel bir araştırma." Pamukkale Journal of Sports Sciences 4, no 2 (2013): 125-45.

Koning, Ruud H. "An Econometric Evaluation of the Effect of Firing a Coach on Team Performance." Applied Economics 35, no. 5 (2003): 555-64.

Müniroğlu, Sürhat, Yunus Yıldırım, ve İzzet Karakulak. "Profesyonel futbolcuların futbolda taktik konusunda görüşlerinin incelenmesi.” Spormetre Beden Eğitimi ve Spor Bilimleri Dergisi IX, no 3 (2011): 97-103. 